judicially:minded person would attach much weight even to a report of his own, drawn up under such circumstances, and all judicially-minded rersons will regret its iniroduction here. Prof. Osborne Reynolds's reasoning proceeds on the hypothesis that the gas is not polarised. The only real question here is, Is Prof. Schuster prepared to maintain that this reasoning is correct?

Prof. Schuster, in reporting his reminiscences, first recites a kinetic principle which is quite consistent with there being as much force sideways as perpendicularly to the disc, and which therefore contains no explanation of the phenomenon ; and when he comes to the first essential point, viz., that which requires him to show that "an increased pressure on the cold side of the vanes of a radiometer will not counterbalance the force acting on the blackened sides," all that he has to say on the subject is that "he does not think that such is the case!" This is the essential thing to be proved before the explanation can be accepted, and he recites experiments which show that it is essential.

Prof. Schuster concludes this part of his letter with the admission that "he does not see how [on his theory] an increase in the force can take place" as the exhaustion proceeds. So much the worse for the theory, since experiment indicates that such an increase in the force does take place. In proof of this I may allege, in addition to Mr. Crookes's experiments, several series of experiments made by Mr. Moss, one of the most judicially-minded, patient, and dexterous manipulators I have met with. The experiments were made with the apparatus described in a communication from him and myself, published last spring in the Proceedings of the Royal Society, and the effect of the convection current was with extreme care excluded in two ways-by placing the swinging disc where the influence of the convection current on it before and behind was balanced, and by observing the motions that arose before the conveclion current had time to reach the disc. Both methods concurred in showing that, as in Mr. Crookes's experiments, the force on the disc; uniformly increased with increasing attenuation of the gas up to the limit to which we pushed the exhaustion. Mr. Crookes has shown that beyond that limit it begins to decrease. Prof. Schuster will do a real service to science if he will devote his great skill for some months to repeating these and other concurrent experiments, and either confirm them or point out why they should be set aside.

Prof. Schuster thinks that "any theory of the radiometer which makes the action depend on the comparatively large [? small] ratio of the mean free path to the dimensions of the vessel, must necessarily be wrong." Has not Prof. Schuster here overlooked the minuteness of the phenomenon which has to be accounted for? Spheroidal drops of less than a millimetre diameter are easily formed of several light liquids. The Crookes's stress which supports these is an excess of vertical stress over horizontal stress in the supporting layer of polarised gas, amounting to about the 12-or 15 -thousandth part of the whole stress. This compares favourably with the minute ratio to which Prof. Schuster refers.

I will not at present enter on that part of Prof. Schuster's letter in which he criticises my published views on penetration, as he refers me to the researches of Messrs. Kundt and Warburg, which I have not yet seen. G. JOHNSTONE STONEY

\section{Glaciation of Orkney}

IAST spring Prof. Geikie informed me of a correspondence which was going on in the columns of NATURE as to the guestion whether the Orkney Islands bore evidence of having been glaciated. It was with much surprise that I heard that there could be any question on this point at all, but I refrained from submitting my opinion to the public-unhesitating though that opinion was-on account of my being then just about starting for my native county, and thus having an opportunity of very specially directing my attention anew to the matter. As the observations I then made without exception tended to confirm me in what really required no confirmation; I think I may now come forward as one who has for long known those islands, and who has made a very special geognostic survey of them, during many years. And I would first say, as regards the question, "whether Orkney does or does not give proof of having been covered by a great ice-sheet?" that I believe that no one who lias educated his eye-not by looking at pictures in books, but among the rocks themselves-to the apprehension and recognition of the hill-contours of an ice-scalped country, would hesitate to declare Orkney to be such. Let such a one take his stand, at a sufficient altitude, anywhere a'ong the north ccast of
Sutherland, with a scratched and polished boss under bis feet, rolling up into rounded hillocks on every side, and sweep his eye from the two Ben Griams over to Hoy, and he could not but exclaim, "There is a country which has suffered sore."

In having to differ from Mr. Laing, I juin issue with him on two points-boulders and foreign stones, and boulder-clay. I have also to corroborate Prof. Geikie as to glaciation near Stromness: for I, during last summer, saw to the immediate north-west of Stromness a surface of gneiss, say ten feet by three, most unmis. takably glaciated-both scratches and polishing being shown.

Now as regards "boulders and foreign stones." Mr. Laing will find-I wonder at his not knowing of it--about 100 yards to the west of the House of Saval, in Sanday, one of the finest boulders in Scotland. This boulder, of great size, consists of horn. blendic gneiss; for long I was unable to identify it with any variety of the hornblendic gneiss of Sutherland; but this very year's work enables me to say that it is very similar to that of a locality near Dulness. In all probability, however, its parent rock lay east, not west.

Another boulder I have heard of, but not seen; it was described to me under the name of the "Eagle Stone"; it lies upon the side of a hill in Westray, near Pierowall, and is said to be peculiar as a loose stone, both on account of its toppling position, its being different from any rock in Orkney, and from there being no rock near it.

As to there being "foreign stones" in Orkney, I shall only say that I have at present in my collection polished jaspers, picked up in rolled masses in Orkney; and that fragments of broken agates are found not unfrequently, on the hill tops and sides, in Hoy. These are quotations, ex grege.

Mr. Laing's very precise observations on the clay beds-let us call them-do call for special investigation.

If the conclusions arrived at by other observers are found to coincide with his--while they could not affect the uitimate decision as regards the ice-clad country-they certainly would strike these clay beds out of the category of boulder-clays. But, sir, I have seen these clays, and I did not see what Mr. Laing saw; and what I did observe leads me to doubt the correctness of his conclusions. For I found it to be a notable circumstance as regards these Orkney clay-beds that they are very markedly clay-beds; i.e., that the amount of clay relatively to that of the stoney matter therein is very much greater than that of most boulder-clays.

Now this is a fact which saps the very foundation of $\mathrm{Mr}$. Laing's observation -an abnormally argillaceous clay bed being the result of the disintegration of a normally siliceous sandstone is difficult to conceive. Nay more, although the cement of certain of the Orkney beds is silicate of alumina, forming the blue argillaceous flag, it is an unquestionable fact, that these flags do not disintegrate by the action of the weather. Even the Picts knew that when they built their Broughs thereof. Silicate of alumina is not affected by carbonated waters.

Upon-nearly all along-the west shore of Shapinsha there are cliffs-sea-cliffs of these clay beds, which lie betwixt the rocks, or the last visible rock, and the 'sea; that last rock is a red ferruginous loose-grained sandstone, with little or no cement, what there is being micaceous; the clay beds are ochre yellow. The disintegration of this rock never could have yielded these clay' beds.

But Mr. Laing may argue that they resulted from the decay of an overlying argillaceous bed. The argument will not stand. Firstly, because the dip is the wrong way; the rock dips at a high angle to the east; the clay slighily caps it, and stands as a bank between its escarpment and the sea. Secondly, because a friable yellow freestone, destitute of argillaceous cement, should overlie the red beds. Thirdly, because on the other side of the bay where the argillaceous flags do appear they are quite permanent. Ice might grind them up-the "weather" does not rot them down. But here no clay beds are seen.

Finally, sir, I would request my talented countryman-whom I have great pleasure in breaking a lance with in this field-to consider how or why it is that these clay beds are found only on one side of the long depression which runs up the centre of the islands?

M. Forster HeDDLE

University, St. Andrews, December 19, I877

\section{Northern Affinities of Chilian Insects}

I THINK I may be allowed to express my surprise at $\mathrm{Mr}$. Mc-Lachlan's statement that this subject has never yet been 